\title{
Analysis of the Proportion of Incidental Water in Annual Wastewater Inflows to a Selected Treatment Plant During a 15-year Observation Period
}

\author{
Grzegorz Kaczor ${ }^{1 *}$, Agnieszka Cupak ${ }^{1}$
}

1 Department of Sanitary Engineering and Water Management, Faculty of Environmental Engineering and Land Surveying, al. Mickiewicza 24-28, 30-059 Krakow, Poland

* Corresponding author's e-mail: grzegorz.kaczor@urk.edu.pl

\begin{abstract}
The main aim of the study was to determine whether the amount and share of incidental water in wastewater inflows to the wastewater treatment plant increased with the age and development of the sewage system. The object of the study is a small sewerage system located in southern Poland, in the Lesser Poland Province, $15 \mathrm{~km}$ northeast of the Kraków city. The analysis of a 15-year observation series of daily wastewater flows, from 01.01.1994 to 31.12.2018, allowed a reliable assessment of the actions taken by the sewage system operator to reduce the sources of incidental water inflow to the sewage network. The study showed that the percentage share of incidental waters in the annual wastewater inflow to the analysed treatment plant decreased from $35.9 \%$ in 2004 to $8.4 \%$ in 2018. This reduction should be treated as a success of the remedial actions of the sewage system operator. However, the study showed at the same time that in 2017 alone, $56709 \mathrm{~m}^{3}$ of incidental water flowed into the analysed sewerage system, compared to $166075 \mathrm{~m}^{3}$ of wastewater. A similar case was repeated in 2013, when $53060 \mathrm{~m}^{3}$ of incidental water and $132860 \mathrm{~m}^{3}$ of real wastewater flowed into the treatment plant. These cases show that all remedial measures by the network operator are still insufficient when heavy precipitation occurs in a given year for a long period of time.
\end{abstract}

Keywords: sewerage system, wastewater, incidental water

\section{INTRODUCTION}

The most important principles of the European environmental policy until 2020 and in the perspective until 2050 are protection, preservation and improvement of the natural capital of the EU as well as protection of its inhabitants from environment-related pressures and threats to health and well-being [https://europa.eu/european-union/topics/environment_pl]. In terms of these tasks, adequate and effective protection of surface and groundwater quality is particularly important.

The greatest threat to these waters are anthropogenic factors, in particular point source pollution, such as municipal and industrial wastewater discharges [Chmielowski et al. 2016, Młyńska et al. 2017, Siwiec et al. 2017,
Cupak et al. 2019, Szeląg et al. 2021]. Hence, continuous monitoring and multi directional measures for improving the quality of treated wastewater discharged to surface waters are necessary [Bugajski et al. 2016, Chmielowski et al. 2017, Nowobilska-Majewska and Bugajski 2020]. At present, the most important task is to support the correct and efficient operation of wastewater treatment plants operating in small rural or settlement sewerage systems. One of the factors hindering the operation of small sewage treatment plants is uncontrolled inflow of infiltration and incidental water to the sewerage network [Weiss et al. 2002, Kaczor 2012, Pawlowski et al. 2014]. The greatest operational problems are generated by incidental waters, because due to their volume they may cause hydraulic overloading of the sewer 
network, pumping stations and, first, individual technological devices of the wastewater treatment plant [Młyński et al. 2016, Kaczor et al. 2017, Bugajski et al. 2019]. At the same time, it should be mentioned that incidental waters flowing to the treatment plant also negatively affect the economics of pollution removal, increasing the costs of energy demand, chemical compounds used in the process, and labour costs [Karpf and Krebs 2011, Ellis and Bertrand-Krajewski 2010]. The main source of incidental water in the sanitary sewerage system is rainwater or snowmelt, which enters the sewerage collectors through sewage manholes and, above all, through illegal connections of roof gutters to sewerage connections [Kaczor 2012, Kaczor and Bugajski 2012, Bugajski et al. 2017]. This problem is faced by sewage system operators in many countries [Brombach et al. 2005, Tibbetts 2005, Birch et al. 2010, Birch et al. 2011, Thorndahl et al. 2015]. At the same time, there is continuous research on the possibilities to detect and calculate the volume of these waters [Schilperoort 2004, Ellis and Bertrand-Krajewski 2010]. However, the content of many publications shows that this problem can be largely solved or reduced by effective quality control of the construction of sewer networks and house sewers, as well as effective search for and removal of illegal rainwater connections and poorly constructed sewer manhole finials [De Bénédittis 2004, Kaczor 2012]. Long-term monitoring of daily wastewater flows makes it possible to determine the volume of influent incidental water and to assess the effectiveness of any measures taken to seal the network and eliminate sources of inflow of incidental water to the sanitary sewer system [De Bénédittis 2004].

The study analysed the wastewater and incidental water inflows to a selected small rural wastewater treatment plant during a 15-year observation period. Such a long study period allows a full and detailed analysis and assessment of the issue in question, taking into account all the relevant factors.

The main aim of the study was to determine whether the amount of incidental water increases with the age and development of the sewer system, and whether the actions taken by network operators contribute to reducing the inflow of these waters into the analysed sewer system during the 15-year observation period.

\section{MATERIALS AND METHODS}

\section{Object of reserches}

The object of the study is a small sewerage system located in southern Poland, in the Lesser Poland Province, $15 \mathrm{~km}$ north-east of the Kraków city. In 2004, when the sewerage system and treatment plant were commissioned, the length of the sanitary gravity sewerage network was $4.6 \mathrm{~km}$, in the year of completion of the study (2018) it had a length of $36.1 \mathrm{~km}$ (Table 1). The sewerage network is made of PVC pipes with diameters: 200, $250,300,350$ and $400 \mathrm{~mm}$, laid at a depth of 1.6 to $3.5 \mathrm{~m}$ below ground level. The number of households and inhabitants using the sewerage system is shown in Table 1. Wastewater, mainly domestic sewage, is discharged from the sewerage system to the mechanical-biological wastewater treatment plant with a capacity of $563 \mathrm{~m}^{3} \cdot \mathrm{d}^{-1}$.

The wastewater treatment process consists of a Huber screen, Imhoff primary settling tank, flowthrough biological reactor with separate aerobic and anoxic zones and a vertical secondary settling tank. The wastewater in the aeration reactor is treated with fine bubbling system. The reactor allows for biological removal of nitrogen, while phosphorus is removed from wastewater in the secondary settling tank, after application of PIX. Currently, the average daily inflow of wastewater to the plant is $522 \mathrm{~m}^{3} \cdot \mathrm{d}^{-1}$ during rainless weather.

\section{RESEARCH METHODOLOGY}

The measurement data of daily wastewater flows were used in this study. This parameter was measured at the treated wastewater outflow from the treatment plant to the receiver using a Prosonic S FDU 90 Endress+Hauser ultrasonic flow meter. The measurement error of the effluent level was $+/-2 \mathrm{~mm}$. The continuous testing period was from 01.01.1994 to 31.12.2018. The measurement of wastewater flows was carried out daily at 7:00 a.m. and the measurement value was automatically recorded on a computer server archiving the operation parameters of the treatment plant. An OP2 tipping bucket rain gauge was also installed at the treatment plant; it was connected to a Mini Log B Endress+Hauser pulse data logger. The information on the occurrence and amount of rainfall was helpful in establishing the rain-free period. A dry period was defined as any 
Table 1. General information on the length of the sewer network and the number of its users

\begin{tabular}{|c|c|c|c|}
\hline Year of study & $\begin{array}{c}\text { Length of sewer network } \\
(\mathrm{km})\end{array}$ & $\begin{array}{c}\text { Number of households connected } \\
\text { to the network }(-)\end{array}$ & $\begin{array}{c}\text { Number of inhabitants using } \\
\text { of sewer (PE) }\end{array}$ \\
\hline 2004 & 4.6 & 138 & 488 \\
2005 & 6.7 & 200 & 700 \\
2006 & 8.8 & 262 & 913 \\
2007 & 10.8 & 324 & 1126 \\
2008 & 13.0 & 389 & 1339 \\
2009 & 15.2 & 454 & 1552 \\
2010 & 17.4 & 519 & 1765 \\
2011 & 17.5 & 522 & 1978 \\
2012 & 21.4 & 640 & 2192 \\
2013 & 23.9 & 715 & 2404 \\
2014 & 26.3 & 785 & 2617 \\
2015 & 28.7 & 857 & 2830 \\
2016 & 31.0 & 927 & 3044 \\
2017 & 33.5 & 1001 & 3257 \\
2018 & 36.1 & 1077 & 3470 \\
\hline
\end{tabular}

day during which the total rainfall did not exceed $5 \mathrm{~mm}$ and the last rainfall greater than $5 \mathrm{~mm}$ occurred not earlier than 2 days before. The latter condition was intended to exclude increased sewage flows resulting from heavy recent rainfall and sewer retention from the dry weather period. After separating, for a given calendar year, the nonrainy periods during which only domestic sewage (without external waters) entered the sewage system, the value of average daily inflow of specific sewage $\mathrm{q}_{\dot{\mathrm{sc}}}$ was calculated together with the value of standard deviation $\sigma_{\hat{s c}}$. The daily inflow of incidental water to the sewerage system, during wet weather, was calculated using Eq. (1):

$$
q_{p}=q_{d}-\left(q_{\dot{s} \dot{c}}+\sigma_{\dot{s}}\right)
$$

where: $q_{p}$ - daily inflow of incidental water to the treatment plant during wet weather $\left(m^{3} \cdot d^{-1}\right)$,

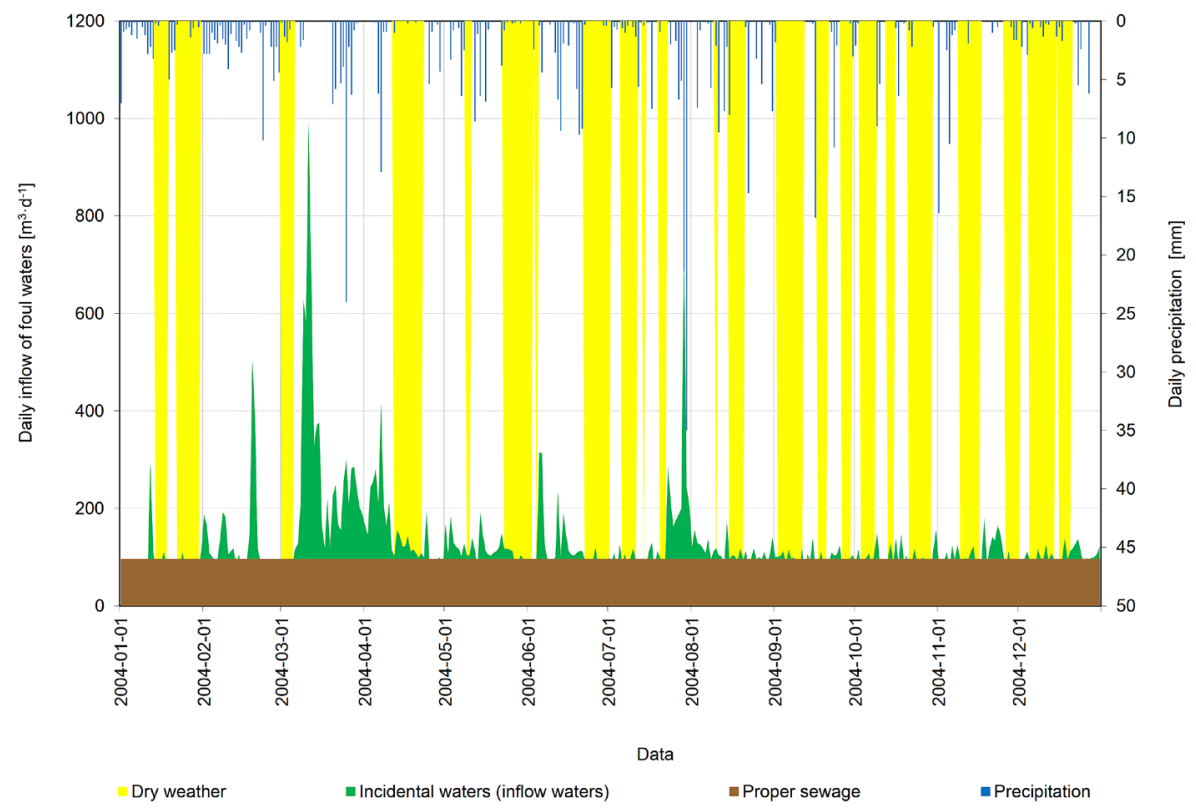

Figure 1. Daily inflows of wastewater and incidental water to the studied wastewater treatment plant in 2004 in comparison with daily 
$q_{d}$ - daily inflow of sewage and incidental water to the treatment plant during wet weather $\left(\mathrm{m}^{3} \cdot \mathrm{d}^{-1}\right)$,

$q_{\hat{s} \dot{c}}-$ daily inflow of domestic sewage to the treatment plant during dry weather $\left(\mathrm{m}^{3} \cdot \mathrm{d}^{-1}\right)$,

$\sigma_{\text {ść }}-$ standard deviation of daily sewage flow during dry weather $\left(\mathrm{m}^{3} \cdot \mathrm{d}^{-1}\right)$.

The value $q_{\text {ść }}+\sigma_{\text {ść }}$ was taken as the cut-off level separating proper sewage from incidental waters. Figure 1 shows an example of daily inflows of proper sewage and incidental waters to the studied wastewater treatment plant in 2004. In addition, the diagram shows the time periods of rainless weather and daily precipitation amounts.

For each year of the study, the summed daily flows of proper sewage, incidental water and sewage and incidental water were calculated separately.

In the papers of many authors [Pecher 1999, Ellis and Bertrand-Krajewski 2010, Bugajski et al. 2017], the amount of incidental waters was expressed by the value of the index of their share in the annual or daily inflow of wastewater to the treatment plant:

$$
S I W=\frac{\sum_{i=1}^{365} q_{p}}{\sum_{i=1}^{365} q_{d}} \cdot 100
$$

where: SIW - annual shares of incidental waters in the inflow to the treatment plant $(\%)$, $\sum_{i=1}^{365} q_{p}-$ total annual inflow of incidental water to the treatment plant $\left(\mathrm{m}^{3}\right)$, $\sum_{i=1}^{365} q_{d}-$ total annual inflow of all polluted waters to the treatment plant (wastewater and incidental waters combined) $\left(\mathrm{m}^{3}\right)$.

\section{RESULTS AND DISCUSSION}

Table 2 presents - separately for each calendar year - total inflows of wastewater, incidental water, wastewater and incidental water together. In addition, the table includes the values for the proportion of accidental waters in the annual sewage inflow to the analysed treatment plant, calculated using Eq. (2). The last column of the table shows unit amount of the sewage $q_{j}$, per sewerage user $(P E)$.

The data obtained show that each year the volume of incidental water increased by $1942 \mathrm{~m}^{3}$ on average. In 2004, $17087 \mathrm{~m}^{3}$ of incidental water flowed into the analysed sewerage system, in 2017 this volume increased by $332 \%$ to a volume of $56709 \mathrm{~m}^{3}$. Thus, it can be considered that the annual volume of incidental water increased with the utilisation of the sewerage system and could be an indication of increasing leakage in the sewerage system. However, at the same time it should be noted that in 15 years the length of the sewer network increased from $4.6 \mathrm{~km}$ up to $36.1 \mathrm{~km}$ and the number of households connected to the sewer

Table 2. Summary of annual inflows of proper sewage and incidental waters to the analysed treatment plant

\begin{tabular}{|c|c|c|c|c|c|}
\hline \multirow{2}{*}{ Year } & \multicolumn{2}{|c|}{ Annual inflows to sewage systems and treatment plants $\left(\mathrm{m}^{3}\right)$} & \multirow{2}{*}{$\begin{array}{c}\text { SIW } \\
(\%)\end{array}$} & $\begin{array}{c}\mathrm{q}_{\mathrm{j}} \\
\left(\mathrm{dm}^{3} \cdot \mathrm{PE}^{-1} \cdot \mathrm{d}^{-1}\right)\end{array}$ \\
\cline { 2 - 5 } & Proper sewage & Incidental waters & All kinds of waters & 35.9 & 267.5 \\
2004 & 30524 & 17087 & 47611 & 20.9 & 174.5 \\
2005 & 35296 & 9307 & 44603 & 25.4 & 189.3 \\
2007 & 47085 & 16021 & 63106 & 26.0 & 255.5 \\
2008 & 58035 & 46997 & 105032 & 28.3 & 195.3 \\
2009 & 68442 & 26986 & 95428 & 23.4 & 144.5 \\
2010 & 62780 & 19127 & 81907 & 22.7 & 250.0 \\
2011 & 124465 & 36632 & 161097 & 24.4 & 210.5 \\
2012 & 114975 & 37036 & 152011 & 16.2 & 156.6 \\
2013 & 105042 & 20251 & 125293 & 28.5 & 211.8 \\
2014 & 132860 & 53060 & 185920 & 17.9 & 209.4 \\
2015 & 164250 & 35750 & 200000 & 14.7 & 181.4 \\
2016 & 159870 & 27523 & 187393 & 14.2 & 179.7 \\
2017 & 171288 & 28373 & 199661 & 25.5 & 187.4 \\
2018 & 166075 & 56709 & 222784 & 8.4 & 161.4 \\
\hline
\end{tabular}


increased from 138 to 1077 . The increase in the length of the sewer network and connections to buildings generally generates a marked increase in the sources of incidental water (more sewage wells and more buildings with the possibility of connecting roof gutters to house sewers).

In order to correctly assess the load of the analysed treatment plant with incidental water it is necessary to analyse the course of the trend line of the share of incidental water on the time axis. This relationship will show the real state of sensitivity of the sewage network to incidental water inflows. In order to use statistical tools in the analysis, the statistical distribution of the SIW values must be examined. In the Shapiro-Wilk test, the $\mathrm{W}$ statistic was 0.926 and the $\mathrm{p}$-value $=0.267$ for an accepted level of $p=0.05$. Thus, there were no grounds to reject the hypothesis $\mathrm{H}_{0}$ stating the normality of the analysed data.

Figure 2 shows the linear regression relationship between the SIW value, expressed as a percentage, and the year of study. The SIW values for 2005 and for 2017 were excluded from the regression analysis as outliers, confirmed by the Dixon and Grubbs test. The remaining data, in the range of $75 \%\left(\mathrm{r}^{2}\right.$ value), are described by a linear relationship with the Eq. (3):

$$
\mathrm{SIW}=-1.5442 \cdot(\text { year })+3127.4
$$

The F-value of the Fisher-Snedecor statistic, for the regression equation, was 33.177 , while the p-value $=0.00013$ for an assumed significance level of $p=0.05$. Thus, there were no grounds to reject hypothesis $\mathrm{H}_{0}$ stating the significance of a linear relationship between the analysed variables. The Student's t-test also confirmed the significance of the directional coefficient $(p$-value $=0.000127)$ and the intercept (p-value $=0.0000001$ ).

The obtained parameters of linear regression equation indicate that the share of incidental water in the inflow to the treatment plant decreased every year by $1.544 \%$. During the analysed 15 years, the value of SIW decreased on average from 32.8 to $11.2 \%$ (Figure 2).

This confirms that the remedial action taken by the operators of the analysed sewerage system have had the expected positive effect. In order to confirm this thesis, the graph presented in Figure 3 was created. It shows a simulation calculated on the basis of the data from the period 2005-2008, when the share of incidental water was subject to an average increase of $2.28 \%$ per year. This increase was related to the length of the network and the number of buildings connected to the sewerage system in 2005-2008, and then proportionally related to the length of the network and the number of buildings in 2018. The presented relationship shows that if no actions were taken to improve the tightness of the sewerage network against incidental water inflows, this share could be close to $64.7 \%$ (red line).

The presented results of calculations show that the SIW indicator gives a better reflect the

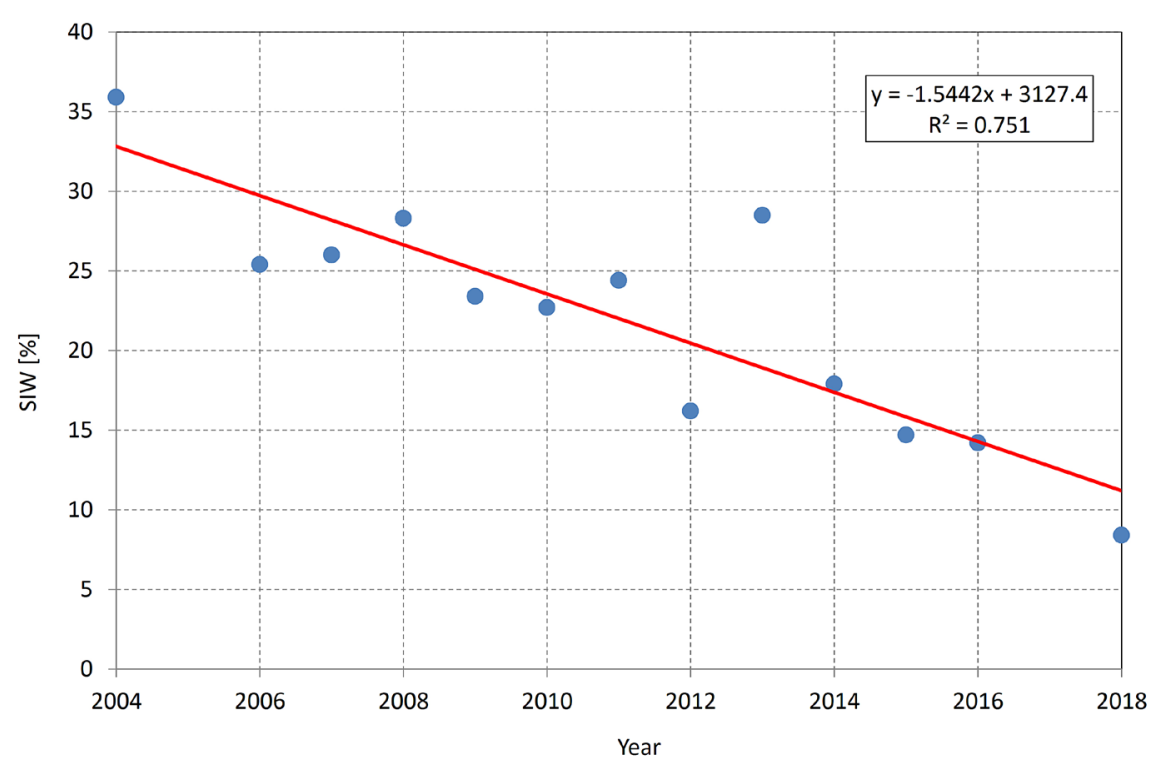

Figure 2. Regressive relationship showing the reduction of the SIW value in each study year 


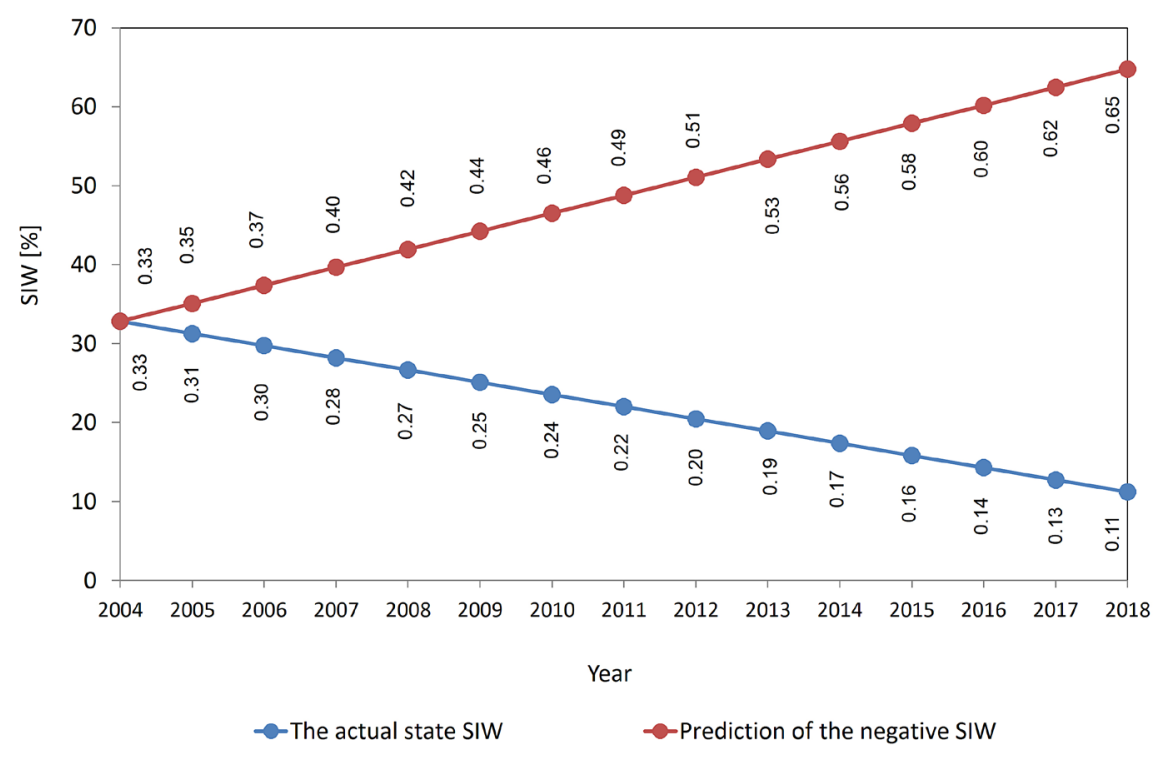

Figure 3. Comparison of the real trend in the reduction of the SIW value in each year against a negative forecast of this indicator

incidental water load in sewer networks and treatment plants than the incidental water value itself, given in $\mathrm{m}^{3} \cdot$ year-1 $^{-1}$ or $\mathrm{m}^{3} \cdot \mathrm{d}^{-1}$.

An interview with the operator of the analysed sewerage system revealed that the greatest impact on the elimination of potential sources of incidental water was:

- smoke testing and video inspections of the interior of sewerage collectors to detect and eliminate illegal or mistaken connections of roof gutters to sewers;

- replacing manholes and improving their place to the road surface by using rings to distance the manhole tops;

- placing greater emphasis on acceptance testing of new sewerage network sections and new connections to buildings;

- environmental education of network users and introduction of charges with reduction of natural land retention.

A significant reduction in the inflow of incidental water to the analysed sewer network is also indicated by the value of daily sewage volume $q_{j}$, calculated per 1 user of the network (Table 2). In 2004, during the start-up of the sewage treatment plant, this value was $267.5 \mathrm{dm}^{3} \cdot \mathrm{PE}^{-1} \cdot \mathrm{d}^{-1}$. It indicated a very careless technical acceptance after the network construction, as it is overestimated probably by more than $100 \mathrm{dm}^{3} \cdot \mathrm{PE}^{-1} \cdot \mathrm{d}^{-1}$. Since 2013, this value has decreased from 211.8 to $161.4 \mathrm{dm}^{3} \cdot \mathrm{PE}^{-1} \cdot \mathrm{d}^{-1}$ in 2018 . This indicator shows that some incidental water still flows into the network in 2018, but it already represents only $11.4 \mathrm{dm}^{3} \cdot \mathrm{PE}^{-1} \cdot \mathrm{d}^{-1}$, because during dry weather this indicator was on average $150 \mathrm{dm}^{3} \cdot \mathrm{PE}^{-1} \cdot \mathrm{d}^{-1}$.

The results obtained in this study should be referred to the results obtained by other authors. Weiss et al. [2002] investigating the share of incidental water in the sewerage systems of BadenWurttemberg, obtained a value of SIW equal to $35 \%$, i.e. similar to that in the analysed sewerage system in 2004. A study by Krachta and Gujera [2005], carried out in Switzerland, found some incidental water in the inflows to wastewater treatment plants ranging from 35 to $65 \%$. These results accurately reflect the extent of the negative prediction and confirm the predicted increase in the SIW without remedial action. A study in Norway, carried out by ØDEGARD [Hey et al. 2016] in 14 sewerage systems, showed that the proportion of incidental water was on average $67 \%$ (this value correlates with the negative forecast results obtained in this study). In contrast, in the Netherlands, the value of the SIW in the study by Schilperoort [2004] was 38\%, while in Austria - from 25 to $50 \%$ [Ertl et al. 2008]. On the basis of the study by Kaczor [2002], conducted in 5 sewer systems in Poland, in the Małopolska Province, the SIW value was between 15.8 and $57.7 \%$. In the study by Bugajski et al. [2017], also performed for a site in Poland, the SIW value averaged 36.2\%.

Despite the noticeable improvement in the average value of the SIW factor, the annual inflow of incidental water to the analysed sewerage system in 2017 is alarming at the same time (Table 2). 
This accounted for $56709 \mathrm{~m}^{3}$ of incidental water and $166075 \mathrm{~m}^{3}$ of proper sewage. A similar case was repeated in 2013, when $53060 \mathrm{~m}^{3}$ of incidental water and $132860 \mathrm{~m}^{3}$ of proper sewage flowed into the treatment plant. The analysis of the rainfall recorded by the rain gauge showed that in 2013, in May and June the total rainfall was $271.2 \mathrm{~mm}$, representing $42 \%$ of the annual total. Heavy rainfall, during the months mentioned, caused hydraulic overloading of the treatment plant and inflow of increased incidental water. In 2017, the total rainfall in July, August and September was $331.5 \mathrm{~mm}$, corresponding to $49.3 \%$ of the annual total. These cases show that any remedial action by the network operator is not sufficient when heavy and long-duration precipitation occurs in a given year.

\section{CONCLUSIONS}

Summarizing the obtained results, it may be stated that the share of incidental waters in the inflow to the analysed sewerage system in 2004 (at the beginning of the study period) was at an average level in comparison with other objects in Poland and worldwide.

On the basis of the forecast carried out, it was shown that the absence of the actions to improve the tightness of the sewerage system could lead to a situation such as that observed at some sites in Switzerland and Norway, where incidental water accounted for more than $60 \%$ of the annual inflow to the treatment plant.

Against the background of the results obtained by other authors, the activities and corrective actions of the operator of the examined sewer network, which led to a decrease in the value of SIW from $35.9 \%$ in 2004 to $8.4 \%$ in 2018 , should be positively evaluated. Such low values of SIW were not found in any research object described in the literature.

In addition, studies have shown that heavy precipitation with over long period of time, occurring periodically in particular years, despite the remedial actions taken by the network operator, still causes hydraulic overloading of the sewerage and wastewater treatment plants.

In summary, it should be stated that the longterm continuous observation of daily sewage flows allows for a very detailed analysis of the functioning of the sewage network and wastewater treatment plants. They allow irregularities in the operation of these facilities to be detected and the effects of remedial actions to be effectively assessed.

\section{REFERENCES}

1. Birch G.F., Cruickshank B., Davis B. 2010. Modelling nutrient loads to Sydney estuary (Australia). Environmental monitoring and assessment, 167, 333-348.

2. Birch H., Mikkelsen P.S., Jensen J.K, Lutzhoft H.C. 2011. Micropollutants in stormwater runoff and combined sewer overflow in the Copenhagen area, Denmark. Water Science and Technology, 64, 485-493.

3. Brombach H., Weiss G., Fuchs S. 2005. A new database on urban runoff pollution: comparison of separate and combined sewer systems. Water Science \& Technology, 51(2), 119-128.

4. Bugajski P., Chmielowski K., Kaczor G. 2016. Reliability of a collective wastewater treatment plant. J. Ecol. Eng. 17(4), 143-147.

5. Bugajski P.M., Kurek K., Młyński D., Operacz A. 2019. Designed and real hydraulic load of household wastewater treatment plants. Journal of Water and Land Development, 40(I-III), 155-160.

6. Bugajski, P., Pawełek, J., Kurek, K. 2017. Concentrations of organic and biogenic pollutants in domestic wastewaterafter mechanical treatment in the aspect of biological reactor design.Infrastruct. Ecol. Rural Areas, IV/3, 1811-1822.

7. Chmielowski K., Bugajski P., Kaczor G. 2016. Compositional analysis of the sewage incoming to and discharged from the sewage treatment plant in Kolbuszowa Dolna. 2016. J. Ecol. Eng., 17(5), 9-16.

8. Chmielowski K., Bugajski P.M., Kaczor G. 2017. Effects of precipitation on the amount and quality of raw sewage entering a sewage treatment plant in Wodzisław Śląski. Journal of Water and Land Development, 34, 85-93.

9. Chmielowski K., Mazur R., Bedla D, Nowak A. 2016. Analiza obciążenia hydraulicznego w oczyszczalni ścieków w Kolbuszowej Dolnej [Analysis of hydraulic load at the sewage treatment plant in Kolbuszowa Dolna], EPISTEME: Czasopismo Naukowo-Kulturalne, 1(30), 319-334.

10. Cupak A., Chmielowski K., Bugajski P., Dacewicz E. 2019. Assessment of efficiency of rural sewage treatment plant with bioreactor. Acta Sci. Pol. Formatio Circumiectus, 18(1), 137-143.

11. De Bénédittis J. 2004. Mesurage de l'infiltration et de l'exfiltration dans les réseaux d'assainissement [Measurement of infiltration and exfiltration in sewage systems]. Le grade de docteur. Villeurbanne, France. INSA de Lyon.

12. Ellis J.B., Bertrand-Krajewski J. 2010. Assessing Infiltration and Exfiltration on the Performance of Urban Sewer Systems. IWA Publishing, UK, London. 
13. Ertl T., Spazierer G., Wildt S. 2008. Estimating groundwater infiltration into seweragesby using the moving minimum method - A survey in Austria. 11th International Conference on Urban Drainage, Edinburgh, Scotland, UK.

14. Hey G., Jónsson K., Mattsson A. 2016. The impact of infiltration and inflow on wastewater treatment plants. A case study in Sweden. Rapport 06, VA-teknik.

15. Kaczor G. 2012. Wpływ wód infiltracyjnych i przypadkowych na funkcjonowanie małych systemów kanalizacyjnych [Effect of infiltration and inflow waters on the performance of small sewer systems]. Rozprawa habilitacyjna. 372, Zeszyty Naukowe Uniwersytetu Rolniczego w Krakowie, 495.

16. Kaczor G., Bugajski P. 2012. Impact of snowmelt inflow on temperature of sewage discharged to treatment plants. Polish Journal of Environmental Studies, 21(2), 381-386.

17. Kaczor G., Chmielowski K., Bugajski P. 2017. Wpływ sumy rocznej opadów atmosferycznych na objętość wód przypadkowych dopływających do kanalizacji sanitarnej [The Effect of Total Annual Precipitation on the Volume of Accidental Water Entering Sanitary Sewage System]. Rocznik Ochrona Środowiska, 19, 668-681.

18. Karpf C., Krebs P. 2011. Quantification of groundwater infiltration and surface water inflows in urban sewer networks based on a multiple model approach. Water Research, 45, 3129-3136.

19. Kracht O., Gujer W. 2005. Quantification of infiltration into sewers based on time series of pollutant loads: Water Science \& Technology, 52, 209-218.

20. Młyńska A., Chmielowski K, Młyński D. 2017. Analysis of sewage quality changes during treatment processes at the wastewater treatment plant in Przemyśl. Ecol. Eng. 5, 18-26.

21. Młyński D., Chmielowski K., Młyńska A. 2016. Analysis of hydraulic load of a wastewater treatment plant in Jasło. Journal of Water and Land Development, 28, 61-67.

22. Nowobilska-Majewska E., Bugajski P. 2020. The Impact of Selected Parameters on the Condition of Activated Sludge in a Biologic Reactor in the Treatment Plant in Nowy Targ, Poland. Water, 12.
23. Pawlowski C.W., Rhea L., Shuster W.D., Barden G. 2014. Some factors affecting inflow and infiltration from residential sources in a core urban area: Case study in Columbus, Ohio, neighborhood. Journal of Hydraulic Engineering, 140, 105-114.

24. Pecher R. 1999. Wody przypadkowe w kanalizacjiProblem gospodarki wodnej [Inflow waters in sewage system - Problem of water management]. Gaz, Woda Technika Sanitarna, 12, 1-6.

25. Schilperoort R.P.S. 2004. Natural water isotopes for the quantification of infiltration and inflow in sewer systems (MSc Thesis). Delft University of Technology, Delft, Netherlands.

26. Siwiec T., Reczek L., Michel M., Gut B., HawerStrojek P., Czajkowska J., Jóźwiakowski K., Gajewska M., Bugajski P. 2018. Correlations between organic pollution indicators in municipal wastewater. Archives of Environmental Protection, 44(4), 50-57.

27. Stan środowiska w województwie małopolskim. Raport. 2020. [The state of the environment in the Małopolskie voivodship. Report]. Główny Inspektorat Ochrony Środowiska, Kraków.

28. Szeląg B., Suligowski R., Drewnowski J., De Paola F., Fernandez-Morales F. J., Bąk Ł. 2021. Simulation of the number of storm overflows considering changes in precipitation dynamics and the urbanisation of the catchment area: a probabilistic approach. Journal of Hydrology, 126275, 12, 1-36.

29. Thorndahl S., Schaarup-Jensen K., Rasmussen M.R. 2015. On hydraulic and pollution effects of converting combined sewer catchments to separate sewer catchments. Urban Water Journal, 12(2), 120-130.

30. Tibbetts J. 2005. Combined sewer systems: down, dirty and out of date. Environmental Health Perspectives, 113(7), 464-467.

31. Weiss G., Brombach H., Haller B. 2002. Infiltration and inflow in combined sewer systems: longterm analysis. Water Science \& Technology, 45(7), 227-230.

32. Zadania europejskiej polityki ochrony środowiska [Tasks of the European environmental policy. (05.2021 https://europa.eu/european-union/topics/ environment_pl). 